\title{
Analisis Penanggulangan Kemiskinan Melalui Implementasi Program Dana Bergulir Badan Amil Zakat Kota Bandung
}

\section{Hani Widyani}

Program Pascasarjana UIN Sunan Gunung Djati, Bandung.

Jl. A. H. Nasution No. 105, Ujung Berung Bandung, Indonesia.

Email: hani.widyani@gmail.com

\begin{abstract}
This article analyzes and evaluates the implementation of poverty alleviation program run by Zakat Collector (BAZ) in Bandung Mucipality. Just like other zakat collectors in Indonesia, BAZ of Bandung Mucipality has various development programs for poverty alleviation, including what is to be called revolving fund project. The aim of revolving fund project is to support the poor to run micro business. Based on fieldwork in Bandung, this article exmanines the problems and difficulties faced by the zakat collector in running development-oriented project and how poverty alleviation are still hard to reach. In evaluating the implementation of poverty alleviation program in Bandung, this article highlights five aspects, including communication, human resource, disposition, bureaucratic structures, and social-economic condition. This article concludes that one of the problems faced by zakat collector is ineffectiveness of communitation between zakat collectors in District and Sub-District levels, as well as lack of capacity among the staff in sub-district level in providing technical assistance for zakat beneficiaries.
\end{abstract}

Keywords: zakat, qardhul hasan, poverty avaliation, revolving fund

\begin{abstract}
ABSTRAK
Artikel ini mengkaji dan mengevaluasi implementasi program penanggulangan kemiskinan yang dilakukan oleh Badan Amil Zakat Kota Bandung. Sebagaimana Badan Amil Zakat lainnya yang ada di Indonesia, BAZ Kota Bandung memiliki program-program pemberdayaan ekonomi untuk kaum miskin, salah satunya dalam bentuk dana bergulir. Dengan menggunakan kajian kualitatif, artikel ini secara khusus menganalisis problematika yang dihadapi oleh BAZ Kota Bandung, termasuk hambatan pelaksanaannya ditinjau dari berbagai aspek, yaitu: 1) Komunikasi; 2) sumber daya; 3) disposisi; dan 4) struktur birokrasi, dan 5) kondisi sosial ekonomi. Berdasarkan hasil kajian lapangan, dapat disimpulkan bahwa hambatan dari implementasi kebijakan program dana bergulir ini adalah minimnya komunikasi dua arah antara BAZ Kota dengan BAZ kecamatan, serta kurangnya kapasitas BAZ kecamatan dalam melakukan pendampingan terhadap penerima dana bergulir.

Kata Kunci: zakat, qardhul hasan, pengentasan kemiskinan, dana bergulir
\end{abstract}

\section{PENDAHULUAN}

Berdasarkan Survei Sosial Ekonomi Daerah (Suseda), penduduk Kota Bandung adalah 2.417.287 jiwa (penduduk laki-laki 1.233.039 jiwa dan perempuan 1.184.248 jiwa). Angka tersebut menentukan Laju Pertumbuhan Penduduk (LPP) sebesar 1,81\%. Diantara Kabupaten/Kota se-Jawa Barat kepadatan penduduk 
tertinggi adalah di Kota Bandung yaitu sebesar 14.491 orang/km2. ${ }^{1}$ Pertumbuhan penduduk adalah perubahan populasi sewaktu-waktu dan dapat dihitung sebagai perubahan dalam jumlah individu dalam sebuah populasi menggunakan "per waktu unit" untuk pengukuran. Pertumbuhan penduduk yang makin cepat, mendorong pertumbuhan aspek-aspek kehidupan yang meliputi aspek sosial, ekonomi, politik, kebudayaan, dan sebagainya. Perkembangan pendudukan di Kota Bandung selama ini menunjukkan peningkatan, dapat dilihat dari jumlah penduduk pada tahun 2010 sebanyak 2.394.873 jiwa menjadi sebanyak 2.412.148 jiwa pada tahun 2011, sehingga Laju Pertumbuhan Penduduk (LPP) Kota Bandung pada tahun 2011 mencapai 1,10\%.

Kemiskinan di Kota Bandung tentunya selalu menjadi topik utama permasalahan yang terjadi dan menjadi salah satu prioritas pemerintah kota (pemkot) Bandung hingga kini. Meski dalam lingkup nasional laporan mengenai jumlah penduduk miskin mengalami penurunan yakni pada kurun waktu tahun 2008-2012 diinformasikan jumlah penduduk miskin berkurang 13,11 juta jiwa atau dari 41,7 juta jiwa menjadi 28,59 juta jiwa namun persoalan kemiskinan tetap urgen diperhatikan secara serius.

Mengacu pada batasan garis kemiskinan yang digunakan BPS, jumlah penduduk miskin di Kota Bandung pada tahun 2008 sebanyak 106.786 jiwa dan meningkat lagi pada tahun 2009 dan 2010 masing-masing sebanyak 110.283 jiwa dan 118.600 jiwa. Pada tahun 2011, kemiskinan penurunan di tahun 2011 menjadi 116.940 jiwa.

Permasalahan sektor ekonomi, sosial, budaya dan lingkungan tidak dapat ditangani oleh pemerintah saja, namun perlu dukungan dunia usaha (swasta dan BUMN). Paradigma mengenai keberlangsungan bisnis (sustainable business) dimana perusahaan memiliki kewajiban untuk membayar kembali (payback) kepada masyarakat, dengan menanggulangi kemiskinan dan mengurangi kelaparan, mengurangi pencemaran lingkungan, menyadari pentingnya hak pekerja, dan kegiatan sosial lainnya pun berlaku. Karena itulah peran korporat sangat penting dalam mereduksi kemiskinan dan pengangguran melalui program CSR ini. Strategi yang dilakukan adalah melalui inclusive business, yaitu melakukan kerjasama dan memberdayakan orang-orang yang kurang mampu. Pendekatan bisnis ini menggabungkan tujuan bisnis perusahaan dengan pengentasan kemiskinan. Keterlibatan perusahaan swasta dalam penanggulangan kemiskinan dapat memberikan dampak yang signifikan terhadap efektivitas penanggulangan kemiskinan. Di bandung, terdapat sekitar 17 perusahaan yang tergabung dalam forum CSR Bandung Bermartabat dan 11 diantaranya adalah perusahaan BUMN.

Dalam konteks panggulangan kemiskinan itu pula, Badan Amil Zakat (BAZ) Kota Bandung dibentuk. Salah satu wujud program pemberdayaan adalah menguatkan ekonomi kaum miskin dengan melibatkan mereka dalam program di bidang ekonomi agar mampu keluar dari kemiskinan. Bentuk program umumnya adalah introduksi penguatan program usaha bagi kelompok miskin dalam bentuk model pembiayaan kebajikan (qardhul hasan). Konsepnya, kelompok miskin diberi pinjaman dana untuk usaha yang besarnya disesuaikan dengan kebutuhan usahanya, kemudian si penerima tadi mengembalikan dalam waktu 
tertentu hanya senilai pokoknya saja dari nilai yang diberikan BAZ tanpa tambahan atau biaya apapun.

Program dana bergulir adalah skim qardhul hasan pada lembaga Badan Amil Zakat Kota Bandung yang dikhususkan bagi pemberdayaan usaha kelompok miskin. Program ini telah berjalan tiga tahun dan selama itu pula telah banyak kelompok miskin yang mengikuti program ini. Dana bergulir yang merupakan salah satu program BAZ dalam penanggulangan kemiskinan di Kota Bandung, pada akhirnya, keberhasilan program diukur sejauh mana tujuan dan manfaat upaya tersebut dapat dicapai dan dinikmati oleh kelompok masyarakat miskin yang menjadi sasaran program. Berdasarkan latar belakang yang sudah dikemukakan di atas, maka masalah yang dianalisis dalam tulisan ini adalah: Bagaimana implementasi kebijakan program dana bergulir BAZ sebagai bentuk penanggulangan kemiskinan melalui program dana bergulir di Kota Bandung? Apa saja hambatan dalam implementasi kebijakan program dana bergulir sebagai bentuk penanggulangan kemiskinan?

\section{METODE PENELITIAN}

Penelitian ini adalah penelitian kualitatif yang dilakukan di Kota Bandung. Fokus penelitian adalah Badan Amil Zakat Kota Bandung. Peneliti mengambil lokasi tersebut karena Kota Bandung memiliki jumlah penduduk dan kegiatan ekonomi terbesar diantara kota-kota di Jawa Barat, dan pada saat yang sama masih disertai dengan tingkat kemiskinan yang besar. Pertama-tama peneliti akan menggambarkan mengenai kebijakan penyaluran program dana bergulir di Badan Amil Zakat Kota Bandung serta permasa- lahan-permasalahan yang timbul dalam pelaksanaannya. Berikutnya peneliti juga akan menganalisis implementasi program dana bergulir dalam penanggulangan kemiskinan.

\section{FILANTROPI ISLAM DAN MASALAH KEMISIKINAN}

Zakat adalah salah satu rukun Islam yang delapan puluh dua ayat al-Quran disebutkan bersama-sama dengan sholat. Kewajiban zakat dibuktikan dengan adanya ayat al-Quran mengenai hal itu dan adanya keterangan hadits Nabi Muhammad SAW serta dengan adanya suatu kewajiban agama. ${ }^{2}$ Dalam konsep Islam, zakat menduduki posisi yang sangat penting. ${ }^{3}$ Zakat adalah nama dari sebuah bentuk aktivitas mengeluarkan sejumlah porsi tertentu dari harta yang telah sampai nishab (batas maksimum) dan cukup satu tahun (haul) untuk dibagikan kepada golongan tertentu yang berhak menerimanya (mustahik). Kata zakat secara etimologi bermakna suci (at-thahir), tumbuh (an-nuwuw) dan berkembang (az-ziyadah). ${ }^{4}$ Pemilihan kata zakat memang sangat sesuai dengan makna tersebut yang sekaligus menggambarkan fungsi dan tujuan zakat. Zakat yang berarti tumbuh, berkembang dan bertambah (nama', grow, develop, increase) dikenakan kepada harta yang telah melebihi jumlah maksimal atau telah sampai nishab (surplus of wealth, al'afw). ${ }^{5}$ Harta yang surplus (lebih) mesti dialirkan kepada kelompok yang mengalami kekurangan (deficit). Islam memandang perlu sebuah mekanisme yang menjamin aliran tersebut benar-benar masuk kepada golongan yang kekurangan tersebut. Zakat memastikan transfer harta kepada kelompok atau golongan yang kurang mampu (the have not) sehingga harta tersebut tidak beredar di kalangan mereka yang berlebih (the have) saja. ${ }^{6}$ 
Dalam ajaran Islam setiap perintah untuk melakukan ibadah mengandung hikmah (signifikansi) yang sangat berguna bagi pelaku ibadah tersebut. Zakat yang secara etimologis bermakna bersih, tumbuh dan baik maka ibadah ini akan memberikan keuntungan bagi para pelakunya. ${ }^{7}$ Terdapat tiga bentuk signifikansi zakat, Pertama signifikansi diniyah (Agama), yaitu: (1) Dengan berzakat berarti telah menjalankan salah satu dari rukun Islam yang menghantarkan seorang hamba kepada kebahagiaan dan keselamatan dunia dan akhirat. (2) Merupakan sarana bagi hamba untuk taqarrub (mendekatkan diri) kepada Rabb nya, akan menambah keimanan karena keberadaannya yang memuat beberapa macam ketaatan. (3) Pembayar zakat akan mendapatkan pahala yang berlipat ganda, sebagaimana firman Allah SWT, yang artinya: "Allah memusnahkan riba dan menyuburkan sedekah" (Al-Baqarah:276). Dalam sebuah hadits muttafaq 'alaih Nabi SAW juga menjelaskan bahwa sedekah dari harta yang baik akan ditumbuhkan kembangkan oleh Allah SWT berlipat ganda. (4) Zakat merupakan sarana penghapus dosa, seperti yang pernah disabdakan Nabi SAW.

Kedua, signifikansi khuluqiyah (Akhlak), yaitu: (1) Menanamkan sifat kemuliaan, rasa toleran dan kelapangan dada kepada pribadi pembayar zakat. (2) Pembayar zakat biasanya indentik dengan sifat rahmah (belas kasih) dan lembut kepada saudaranya yang tidak punya. (3) Merupakan realita bahwa menyumbangkan sesuatu yang bermanfaat baik berupa harta maupun raga bagi kaum muslimin akan melapangkan dada dan meluaskan jiwa. Sebab akan menjadi orang yang dicintai dan dihormati sesuai tingkat pengorbanannya. (4) Di dalam zakat terdapat penyucian terhadap akhlak.
Ketiga, signifikansi ijtimaiyyah (Sosial Kemasyarakatan), yaitu (1) Zakat merupakan sarana untuk membantu dalam memenuhi hajat hidup fakir miskin yang merupakan kelompok mayoritas sebagian besar negara di dunia. (2) Memberikan dorongan kekuatan kepada kaum muslimin dan mengangkat eksistensi mereka. Hal ini tercermin dalam kelompok penerima zakat, salah satunya adalah bagi fi sabilillah. (3) Zakat bisa mengurangi kecemburuan sosial, dendam dan rasa dengki yang ada dalam dada fakir miskin. Karena masyarakat bawah biasanya jika melihat mereka yang berkelas ekonomi tinggi menghambur-hamburkan harta untuk sesuatu yang tidak bermanfaat akan timbul rasa benci dan permusuhan mereka.

Jika harta yang demikian melimpah itu dimanfaatkan untuk mengentaskan kemiskinan tentu akan terjalin keharmonisan dan cinta kasih antara golongan kaya (aghniya) dan golongan miskin (fuqara wal masakin). (4) Zakat akan mendorong pertumbuhan ekonomi pelakunya dan yang jelas berkahnya akan melimpah. (5) Membayar zakat berarti memperluas peredaran harta benda atau uang, karena ketika harta dibelanjakan maka perputarannya akan meluas dan lebih banyak pihak yang dapat mengambil manfaat. Berdasarkan deskripsi tersebut, maka dapat disimpulkan bahwa zakat sebagai sebuah aktifitas ekonomik religius sesuai dengan prinsip-prinsip kepercayaan agama (faith), pemerataan (equity) dan keadilan (social justice), produktifitas dan kematangan, nalar (reason), kebebasan (freedom), dan prinsip etik dan kewajaran. ${ }^{8}$

\section{Kemiskinan dan Penduduk Perkotaan}

Lembaga-lembaga seperti Bank Dunia dan 
Badan Pusat Statistik menjelaskan

kemiskinan sebagai ketidakmampuan untuk memenuhi standar kebutuhan hidup tertentu. Disebutkan dalam Strategi Nasional Penanggulangan Kemiskinan (SNPK) bahwa kemiskinan adalah kondisi di mana seseorang atau sekelompok orang, baik laki-laki maupun perempuan, tidak terpenuhi hakhak dasarnya secara layak untuk menempuh dan mengembangkan kehidupan bermartabat. ${ }^{9}$ Sementara itu, ekonomhumanis seperti Amartya Sen (1999) lebih setuju dengan pandangan bahwa kemiskinan adalah bentuk absennya kemerdekaan (lack of freedom) dan kapabilitas (capabilities) atas diri seseorang yang menyebabkan ia tidak mampu mendapatkan apa yang menjadi hak dasarnya sekaligus menjalankan fungsi-fungsi utamanya (functioning) sebagai individu. Di pihak lain, Oscar Lewis (1959) seorang antropolog Amerika secara lebih tajam bahkan mengajukan teori kontroversial yang menjelaskan kemiskinan sebagai suatu bentuk budaya (the culture of poverty).

Sementara itu, ilmuwan Indonesia seperti Soetandyo Wignjosebroto seperti dikutip oleh Suyanto (1995) mengajukan kemiskinan struktural dimana kemiskinan dipahami sebagai konsekuensi logis dari kondisi struktur atau tatanan kehidupan yang tidak menguntungkan. ${ }^{10}$

Sementara itu dari bahasa aslinya (Arab) kata "miskin" terambil dari kata sakana yang berarti diam atau tenang, yang artinya menjadi diam atau tidak bergerak karena lemah fisik atau sikap yang sabar dan qana'ah. ${ }^{11}$ Menurut Al-Fairuz Abadi dalam AlQamus Al-Muhith "miskin” adalah orang yang tidak punya apa-apa atau orang yang sangat membutuhkan pertolongan. Dan bisa dikatakan miskin orang yang dihinakan oleh kemiskinan atau selainnya. ${ }^{12}$ Selain miskin, dalam Islam ada istilah yang sangat berdekatan, yakni faqir. Faqir berasal dari kata faqr yang pada mulanya berarti tulang punggung. Faqir adalah orang yang patah tulang punggungnya, dalam arti bahwa beban yang dipikulnya sedemikian berat sehingga "mematahkan" tulang punggungnya. ${ }^{13}$ Yusuf Qardhawi, memberikan berbagai argumentasi tentang kemiskinan dan bagaimana Islam memandang kemiskinan. Pemikiran Qardhawi yang dimaksud adalah sebagai berikut: ${ }^{14}$ Harus disebutkan bahwa di kalangan umat Islam terdapat berbagai pandangan tentang kemiskinan.

Di kalangan kaum sufi, kemiskinan bukan suatu kejahatan atau masalah yang harus dihindari. Kemiskinan adalah nikmat Allah SWT. Dengan hidup miskin, manusia akan mampu menggerakkan diri sebagai hamba pilihan-Nya. Kemiskinan akan mendorong hati setiap hamba untuk selalu terkait dengan akhirat, berpaling dari dunia, yang karenanya selalu berhubungan dengan Allah. Sikap golongan sufi yang fatalis sebagaimana digambarkan tadi, memandang kemiskinan bukan sebagai kejahatan dan malapetaka. Ia merupakan ketentuan samawi yang tidak mungkin dipecahkan dan diatasi, kemiskinan dan kekayaan merupakan kehendak (qudrah) dan iradah Allah SWT. Di kalangan kaum sufi, Allah mampu menjadikan semua manusia untuk menjadi kaya raya seperti Karun, atau miskin semua. Adanya kelompok kaya dan kelompok miskin, diciptakan Allah untuk melakukan perlombaan kebaikan.

Di sisi lain, ada juga kelompok Muslim progresif yang memandang kemiskinan sebagai kejahatan dan malapetaka.

Kemiskinan oleh kelompok kedua ini dianggap sebagai persoalan serius yang harus 
TABEL 1

JUMLAH PENDUDUK DAN KEPADATAN PER KECAMATAN, 2010

\begin{tabular}{|c|c|c|c|c|}
\hline NO & KECAMATAN & TOTAL & LUAS (KM2) & $\begin{array}{l}\text { KEPADATAN } \\
\text { PENDUDUK PER } \\
\text { KM2 }\end{array}$ \\
\hline 1 & Bandung Kulon & 138.644 & 6,46 & 21.462 \\
\hline 2 & Babakan Ciparay & 143.203 & 7,45 & 19.222 \\
\hline 3 & Bojongloa Kaler & 117.218 & 3,03 & 38.686 \\
\hline 4 & Bojongloa Kidul & 83.600 & 6,26 & 13.355 \\
\hline 5 & Astana Anyar & 66.658 & 2,89 & 23.065 \\
\hline 6 & Regol & 79.316 & 4,3 & 18.446 \\
\hline 7 & Lengkong & 69.307 & 5,9 & 11.747 \\
\hline 8 & Bandung Kidul & 57.398 & 6,06 & 9.472 \\
\hline 9 & Buah Batu & 92.140 & 7,93 & 11.619 \\
\hline 10 & Rancasari & 72.406 & 7,33 & 9.878 \\
\hline 11 & Gedebage & 34.299 & 9,58 & 3.580 \\
\hline 12 & Cibiru & 67.412 & 6,32 & 10.666 \\
\hline 13 & Panyileukan & 37.691 & 5,1 & 7.390 \\
\hline 14 & Ujung Berung & 72.414 & 6,4 & 11.315 \\
\hline 15 & Cinambo & 23.762 & 3,68 & 6.457 \\
\hline 16 & Arcamanik & 65.607 & 5,87 & 11.177 \\
\hline 17 & Antapani & 72.006 & 3,79 & 18.999 \\
\hline 18 & Mandalajati & 60.825 & 6,67 & 9.119 \\
\hline 19 & Kiaracondong & 127.616 & 6,12 & 20.852 \\
\hline 20 & Batununggal & 116.935 & 5,03 & 23.248 \\
\hline 21 & Sumur Bandung & 34.446 & 3,4 & 10.131 \\
\hline 22 & Andir & 94.361 & 3,71 & 25.434 \\
\hline 23 & Cicendo & 96.491 & 6,86 & 14.066 \\
\hline 24 & Bandung Wetan & 29.807 & 3,39 & 8.793 \\
\hline NO & KECAMATAN & TOTAL & LUAS (KM2) & $\begin{array}{l}\text { KEPADATAN } \\
\text { PENDUDUK PER } \\
\text { KM2 }\end{array}$ \\
\hline 25 & Cibeunying Kidul & 104.575 & 5,25 & 19.919 \\
\hline 26 & Cibeunying Kaler & 68.807 & 4,5 & 15.290 \\
\hline 27 & Coblong & 127.588 & 7,35 & 17.359 \\
\hline 28 & Sukajadi & 104.805 & 4,3 & 24.373 \\
\hline 29 & Sukasari & 79.211 & 6,27 & 12.633 \\
\hline \multirow[t]{6}{*}{30} & Cidadap & 56.325 & 6,11 & 9.218 \\
\hline & Jumlah/Total & 2.394 .873 & 167,31 & 14.314 \\
\hline & 2009 & 2.417 .288 & 167,29 & $14.449,69$ \\
\hline & 2008 & 2.374 .198 & 167,29 & $14.192,11$ \\
\hline & 2007 & 2.329 .928 & 167,29 & $13.927,48$ \\
\hline & 2006 & 2.296 .848 & 167,29 & $13.729,74$ \\
\hline
\end{tabular}

Sumber: BPS Kota Bandung dipecahkan. Kemiskinan, utamanya kemiskinan struktural yang terjadi akibat menguatnya ketidakadilan Antara penguasa dengan rakyat, jurang yang lebar Antara kaum kaya dan kaum papa, harus dieliminir dengan konsep ajaran Islam yang justru dalam banyak hal sangat sosialisme meski tidak indentik dengan sosialisme sebagai faham yang bersifat ideologis, ateis. Kelompok Islam lain adalah pengikut kaum kapitalis yang memandang kemiskinan sebagai salah satu musibah dan problema hidup universal manusia. Namun untuk menyelesaikan kemiskinan, tidaklah tepat untuk diselesaikan oleh institusi negara dan lembaga-lembaga formal lainnya. Bagi kelompok ini, yang bertanggungjawab untuk mengatasi persoalan kemiskinan adalah orang miskin itu sendiri. Dalam hal ini, kemiskinan tidak dapat dianggap sebagai suratan nasib yang ditentukan secara sepihak atas qudrah dan iradah Tuhan. Kemiskinan dan kemakmuran hidup seseorang akan sangat tergantung dari kualitas hidup seseorang ketika berhadapan dengan realitas masyarakat itu sendiri. Bagi kelompok ini, setiap individu hanya bertanggungjawab terhadap dirinya. Setiap individu bebas melakukan apa saja terhadap harta yang dimilikinya. 
Kemiskinan adalah suatu standar tingkat dan taraf hidup dalam skala ekonomi rendah, yaitu mereka yang tingkat ekonominya kekurangan dibandingkan dengan standar kehidupan umum yang berlaku dalam masyarakat bersangkutan. Standar kehidupan yang rendah ini secara langsung nampak pengaruhnya terhadap tingkat keresahan. Kehidupan moral dan rasa harga diri mereka yang tergolong sebagai orang miskin menjadi lebih rendah. ${ }^{15}$ Kemiskinan dan penanggulangannya termasuk persoalan kemasyarakatan, yang faktor penyebab dan tolak ukur kadarnya, dapat berbeda akibat perbedaan lokasi dan situasi. Karena itu, al-Quran dan Hadits tidak menetapkan angka tertentu dan pasti sebagai ukuran kemiskinan, dan tidak memberikan petunjuk operasional yang rinci untuk pengentasannya. Karena itulah para pakar Islam berbeda pendapat dalam menetapkan standar atau tolak ukur dan berusaha menemukan sesuatu dalam ajaran Islam yang dapat digunakan sebagai tolak ukur kemiskinan, yakni dengan menggunakan zakat.

\section{HASIL PENELITIAN DAN PEMBAHASAN Implementasi Program Dana Bergulir Badan Amil Zakat Kota Bandung}

Kota Bandung terletak di wilayah Jawa Barat dan merupakan ibu kota provinsi Jawa Barat. Secara geografis, Kota Bandung terletak pada koordinat 107' 36' Bujur Timur dan 6o 55' Lintang Selatan. Wilayah Kota Bandung dilewati oleh 15 sungai sepanjang $265.05 \mathrm{~km}$, dimana sungai utamanya yaitu Sungai Cikapundung beserta anak-anak sungainya pada umumnya mengalir ke arah selatan dan bermuara ke Sungai Citarum. Wilayah Kota Bandung tersebut dibagi menjadi beberapa wilayah administratif, yang terdiri atas: 30 kecamatan, 151 kelurahan, 1.558 Rukun Warga (RW), dan 9.678 Rukun Tetangga (RT).

\section{Perkembangan pembangunan Kota} Bandung yang pesat, di samping menimbulkan dampak positif bagi kehidupan masyarakat, juga menimbulkan dampak negatif, seperti kemacetan transportasi, dan lain sebagainya. Permasalahan ini terus menjadi perhatian dan pekerjaan rumah bagi Pemerintah Kota Bandung untuk terus memperbaiki diri seiring perkembangan jaman yang semakin modern. Mengacu pada batasan garis kemiskinan yang digunakan BPS, jumlah penduduk miskin di Kota Bandung pada tahun 2008 sebanyak 108.786 jiwa. Meningkat lagi pada tahun 2009 dan 2010 masing-masing sebanyak 110.283 jiwa dan 118.600 jiwa. Mengalami penurunan di tahun 2011 dibandingkan tahun sebelumnya menjadi 116.940 jiwa.

TABEL 2

JUMLAH DAN PERSENTASE PENDUDUK MISKIN DAN GARIS KEMISKINAN

\begin{tabular}{llll} 
TAHUN & $\begin{array}{l}\text { PENDUDUK } \\
\text { MISKIN }\end{array}$ & PERSENTASE & $\begin{array}{l}\text { GARIS } \\
\text { KEMISKINAN }\end{array}$ \\
\hline 2007 & 87,2 & 3,68 & 181.142 \\
\hline 2008 & 106,8 & 4,42 & 209.171 \\
\hline 2009 & 110,28 & 4,50 & 262.093 \\
\hline 2010 & 118,6 & 4,95 & 279.784 \\
\hline 2011 & 116,94 & 4,78 & 292.104 \\
\hline
\end{tabular}

Pemukiman atau perumahan kumuh di Kota Bandung diakibatkan oleh berbagai faktor pemicu baik secara ekonomi maupun keberadaan Kota Bandung itu sendiri, selain itu faktor urbanisasi yang cukup tinggi ke daerah Bandung. Pesatnya urbanisasi dari suatu daerah atau wilayah ke wilayah lainnya yang pada umumnya dari desa ke kota, merupakan salah satu penyebab dari 
keberadaan pemukiman kumuh. Alasan perpindahan penduduk tersebut, adalah merubah keadaan baik secara ekonomi maupun status sosial dengan cara 'mengais' rejeki dan mencari peruntungan di Kota Bandung. Namun yang terjadi adalah urbanisasi ke Kota Bandung menimbulkan persoalan-persoalan baru, antara lain: bertambahnya penduduk miskin, pemukiman kumuh bertambah, meningkatnya kriminalitas, meningkatnya pengangguran dan meningkatnya beban Kota Bandung. Munculnya pemukiman kumuh dilihat dari sisi ketersediaan lahan, yaitu bahwa luas lahan tidak dapat menyediakan warga pendatang.

Pesatnya pertumbuhan daerah perkotaan menyebabkan terjadinya persaingan dalam penggunaan lahan, misalnya antara penggunaan lahan perumahan dengan penggunaan lahan industri atau penggunaan lahan untuk ruang terbuka hijau, pemukiman atau perkantoran. Dari 1556 RW di Kota Bandung, 194 RW diantaranya termasuk ke dalam daerah pemukiman kumuh. Lahan-lahan dengan keadaan seadanya tersebut dapat dijumpai antara lain, lahan sepanjang rel kereta api, pinggiran sungai, dan lain-lain. Pemukiman kumuh di Kota Bandung merupakan bagian yang tidak terpisahkan di Bandung. Adapun yang termasuk dalam daerah kumuh tinggi yaitu Kecamatan Astana Anyar Kelurahan Nyengseret, Kecamatan Bandung Wetan Kelurahan Tamansari, Kecamatan Kiaracondong Kelurahan Babakan Surabaya, Kecamatan Sumur Bandung Kelurahan Braga, dan Kecamatan Bojongloa Kidul Kelurahan Situsaeur. Kondisi rumah-rumah kumuh di Kota Bandung pada umumnya terlihat dalam karakteristik berikut:
1) Ketersediaan air bersih kurang dari 30 persen

2) Sistem drainase buruk

3) Kondisi jalan lingkungan rusak parah lebih dari 70 persen

4) Kepadatan penduduk lebih dari 100 unit rumah per hektar

5) Tidak memiliki jarak antara bangunan

6) Perkembangan bangunan tinggi.

Selain pemukiman kumuh sebagai gambaran masyarakat miskin Kota Bandung, wajah kemiskinan kota juga dapat ditampakkan dengan banyaknya warga yang mengais rejeki dengan cara menjadi pengemis atau pengamen yang beroperasi di berbagai sudut dan wilayah kota. Pada umumnya kelompok pengamen beroperasi di persimpangan lampu merah, atau terminalterminal bus kota, atau bus antar kota atau pertokoan seperti ITC, Yogya Kepatihan yang banyak ditempati kaki lima. Selain dua kelompok yang sudah disebutkan, terdapat pula kelompok warga yang tidak memiliki pekerjaan atau sebagai warga pengangguran. Pengangguran pada kelompok-kelompok ini jelas adalah penduduk atau orang yang tidak memiliki "skill" atau keterampilan khusus yang dapat digunakan sebagai "modal" untuk memperoleh pekerjaan secara permanen pada sektor formal, ataupun ketiadaan modal untuk dapat berwirausaha mandiri, dengan keterbatasan tersebut mereka akan tetap menjadi pengangguran.

\section{Kebijakan Penanggulangan Kemiskinan di Kota Bandung}

Seperti telah dijelaskan sebelumnya bahwa kemiskinan merupakan tanggung jawab dari pemerintah pusat (negara) dan pemerintah daerah. Kewajiban dan tanggung jawab ini 
merujuk pada UUD 1945 pasal 34. ${ }^{16}$ Atas dasar itulah, maka penanggulangan kemiskinan merupakan tugas negara, dimana merujuk pada sistem pemerintahan Indonesia saat ini yang tidak lagi menerapkan sistem kebijakan pusat, maka otonomi daerah menjadikan pemerintah daerah bagian dari pelaksana kebijakan pusat dengan memperhatikan kemampuan-kemampuan lokal bidang keuangan dan sumberdaya lainnya untuk meneruskan pembangunan nasional. Untuk secara bersama-sama menanggulangi masalah kemiskinan sesuai dengan kondisi daerahnya masing-masing.

Kota Bandung adalah salah satu pemerintah daerah yang juga memiliki permasalahan kemiskinan yang harus dapat ditanggulanginya untuk dapat mensejahterakan penduduknya. Dalam hal upaya mengurangi jumlah penduduk miskin di Bandung, pemerintah Kota Bandung telah mengeluarkan berbagai kebijakan, khususnya kebijakan penanggulangan kemiskinan. Seperti telah dijelaskan sebelumnya, bahwa jumlah penduduk miskin di Kota Bandung sampai dengan akhir tahun 2011 adalah 116.904 atau 4,78\% dari total penduduk Kota Bandung.

Menegakkan sistem zakat merupakan salah satu kewajiban utama bagi pemerintah, karena ia memikul tanggung jawab untuk memelihara semua orang fakir-miskin dan orang-orang yang lemah fisik maupun ekonominya. Pemerintah wajib membentuk badan yang dikenal dengan Badan Amil Zakat. Dalam konteks ini, pengertian pemerintah bisa bermakna Pemerintah Pusat maupun Pemerintah Daerah. Dengan dikeluarkannya Surat Perintah Walikota No. 451.12/SE.056-PEG Tahun 2004 tentang Pelaksanaan Zakat Profesi Untuk Pejabat
Eselon II Sampai Dengan IV di Lingkungan Pemkot; kemudian Surat Edaran Walikota No. 451.12/SE.049-KESRA Tahun 2006 Tentang Pengumpulan Zakat, Infaq Dan Shadaqah Bagi Jemaah Haji; dan Surat Edaran Walikota No. 451.12/SE.065-KESRA Tahun 2006 Tentang Pengumpulan Zakat, Infaq Dan Shadaqah/Zakat Profesi, merupakan strategi pemerintah Kota Bandung dengan BAZ untuk mengoptimalkan penghimpunan zakat, yang tentunya penyaluran dana zakat tersebut menjadi salah satu strategi untuk penanggulangan kemiskinan.

\section{Badan Amil Zakat Kota Bandung}

Badan Amil Zakat (BAZ) Kota Bandung yang berada di Jl. Wastukencana No. 27 Bandung, merupakan institusi yang dibentuk oleh pemerintah beserta masyarakat, memiliki tugas mulia dan strategis sebagai salah satu lembaga resmi pemerintah pengelola zakat di kotamadya Bandung, Jawa Barat. Keberadaanya diharapkan mampu menumbuh-kembangkan kesadaran umat Jawa Barat agar menjadikan zakat sebagai sebuah ruh kehidupannya. Dalam pembentukan dan pengelolaan BAZ Kota Bandung, terdapat beberapa landasan yuridis mengenainya, yaitu:

- Seperti tercantum dalam Undang-Undang RI Nomor 38 Tahun 1999 tentang Pengelolaan Zakat.

- Fatwa MUI Pusat No. 3 Tahun 2003 Tentang Zakat Profesi/Penghasilan.

- Peraturan Daerah Kota Bandung No. 30 Tahun 2002 tentang Pengelolaan Zakat, Infaq dan Shadaqah.

- SK Walikota Nomor 452.12/Kep.434KESRA/2009 tentang Pembentukan Pengurus Badan Amil Zakat (BAZ Kota 
Periode 2009 - 2012)

- Keputusan WaliKota Bandung No. 279

Tahun 2004 Tentang Teknis Pengelolaan

Zakat, Infaq Dan Shadaqah.

- Surat Perintah Walikota No. 451.12/

SE.056-PEG Tahun 2004 tentang

Pelaksanaan Zakat Profesi Untuk Pejabat

Eselon II Sampai Dengan IV di

Lingkungan Pemkot.

- Surat Edaran Walikota No. 863/SE.056-

PEG Tahun 2006 Tentang Pembuatan DP3.

- Surat Edaran Walikota No. 451.12/ SE.049-KESRA Tahun 2006 Tentang

Pengumpulan Zakat, Infaq Dan Shadaqah Bagi Jemaah Haji.

- Surat Edaran Walikota No. 451.12/

SE.065-KESRA Tahun 2006 Tentang

Pengumpulan Zakat, Infaq Dan

Shadaqah/Zakat Profesi.

Selama ini pemasukan dana zakat dan infak yang diterima BAZ Kota Bandung sebagian besar dari PNS di lingkungan Pemkot. Sampai dengan 31 Desember 2011 baru 6.631 pegawai $( \pm 23 \%$ ) dari 28.352 para pegawai di lingkungan pemkot Bandung dan Kementrian Agama kantor Kota Bandung. Hasil pengumpulan dari Januari sampai dengan Desember 2011 sebesar Rp. 3. 175. 665. 121,72,- rata-rata perbulan $\mathrm{Rp}$. 264.638.760,-

\section{Pengurus BAZ Kota Bandung}

Susunan kepengurusan BAZ Kota

Bandung terdiri atas Dewan Pertimbangan (1 ketua, 1 wakil ketua, 1 sekretaris, dan 3 anggota); Komisi Pengawas ( 1 ketua, 1 wakil ketua, 1 sekretaris, dan 3 anggota); Badan Pelaksana (1 ketua umum, 2 wakil ketua, 3 sekretaris, 1 bendahara, dan 1 wakil bendahara), yang dilengkapi dengan

beberapa bidang. Yakni: Bidang

Pengumpulan 4 orang, Bidang

Pendayagunaan 4 orang, Bidang

Pendistribusian 4 orang, Bidang

Pengembangan 4 orang, dan Kesekretariatan 8 orang sebagai tenaga kerja penuh waktu.

Berdasarkan pendidikan yang dimiliki:

TABEL 4.3

PROFIL PERSONALIA BAZ KOTA BANDUNG

\begin{tabular}{lccccc}
$\begin{array}{l}\text { PENDIDIKAN } \\
\text { UNIT PENGURUS }\end{array}$ & SLA & S1 & S2 & S3 & JUMLAH \\
\hline Dewan Pertimbangan & 0 & 2 & 4 & 0 & 6 \\
\hline Komite Pengawas & 0 & 3 & 3 & 0 & 6 \\
\hline Badan Pelaksana & 0 & 17 & 6 & 1 & 24 \\
\hline Kesekretariatan & 1 & 6 & 1 & 0 & 8 \\
\hline Jumlah & 5 & 25 & 10 & 1 & 44 \\
\hline
\end{tabular}

Struktur organisasi BAZ Kota Bandung dapat digambarkan sebagai berikut:

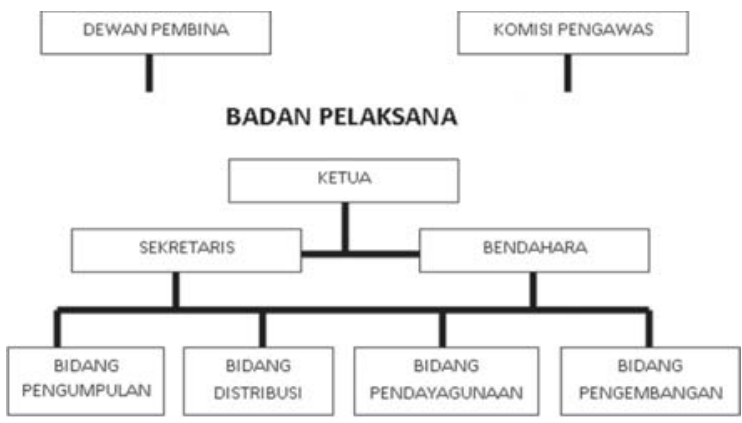

\section{Program Kerja BAZ Kota Bandung}

1) Program Kerja Bidang Pengumpulan (lihat tabel 4.4)

2) Program kerja Bidang Pendistribusian (lihat Tabel 4.5)

\section{Implementasi Kebijakan Program Dana} Bergulir Badan Amil Zakat Kota Bandung

Implementasi program ini dimulai dengan adanya suatu analisis tentang bagaimana 


\begin{tabular}{|c|c|c|c|c|}
\hline NO & PROGRAM & URAIAN KEGIATAN & SASARAN & $\begin{array}{l}\text { TARGET YANG INGIN } \\
\text { DICAPAI }\end{array}$ \\
\hline 1 & $\begin{array}{l}\text { Intensifikasi } \\
\text { pengumpulan } \\
\text { zakat/infaq wajib } \\
\text { profesi pegawai } \\
\text { pemerintah }\end{array}$ & $\begin{array}{l}\text { - Menyusun daftar muzakki tiap } \\
\text { unit kerja di lingkungan } \\
\text { pemkot Bandung } \\
\text { - Menyusun daftar muzakki } \\
\text { berikut besaran ZIS yang telah } \\
\text { dibayarkan pada tiap bulan } \\
\text { - Mengadakan pertemuan } \\
\text { dengan kep. SKPD Bandung, } \\
\text { baik yang telah maupun yang } \\
\text { belum terbentuk UPZ }\end{array}$ & $\begin{array}{l}\text { - Data pada } \\
\text { Bendahara } \\
\text { - Unit kerja/instansi } \\
\text { dan Dinas Pemkot } \\
\text { Bandung } \\
\text { - Data pada } \\
\text { bendahara } \\
\text { - Unit kerja/instansi } \\
\text { dan dinas pemkot } \\
\text { Bandung } \\
\text { - Unit kerja } \\
\text { Dinas/instansi di } \\
\text { Kota Bandung }\end{array}$ & $\begin{array}{l}\text { - Tersedianya data } \\
\text { muzakki yang } \\
\text { lengkap dan } \\
\text { akurat } \\
\text { - Diketahuinya } \\
\text { penerimaan } \\
\text { zakat/infaq wajib } \\
\text { profesi dengan } \\
\text { jelas } \\
\text { - Seluruh } \\
\text { pegawai negeri } \\
\text { yang beragama } \\
\text { Islam menunaikan } \\
\text { zakat profesinya } \\
\text { melalui UPZ dinas } \\
\text { terkait }\end{array}$ \\
\hline 2 & $\begin{array}{l}\text { Ekstensifikasi } \\
\text { pengumpulan } \\
\text { zakat/infaq wajib } \\
\text { instansi lembaga } \\
\text { dan perusahaan } \\
\text { di wilayah Kota } \\
\text { Bandung }\end{array}$ & $\begin{array}{l}\text { - Sosialisasi dan penyuluhan } \\
\text { (dakwah zakat) } \\
\text { - Membuat surat, brosur tentang } \\
\text { zakat/infaq wajib profesi }\end{array}$ & $\begin{array}{l}\text { - Organisasi profesi } \\
\text { dokter dan } \\
\text { pegawai swasta } \\
\text { - Pegawai Bank \& } \\
\text { BUMN/BUMD } \\
\text { yang ada di } \\
\text { wilayah Kota } \\
\text { Bandung } \\
\text { - Calon jamaah haji }\end{array}$ & $\begin{array}{l}\text { - Kadin Kota } \\
\text { Bandung } \\
\text { - IDI Kota Bandung } \\
\text { - Instansi dan BUMN } \\
\text { terkait }\end{array}$ \\
\hline 3 & $\begin{array}{l}\text { Pengumpulan } \\
\text { ZIS }\end{array}$ & Sosialisasi ZIS & $\begin{array}{l}\text { Sadar pentingnya } \\
\text { ZIS di masyarakat } \\
\text { Kota Bandung }\end{array}$ & Masyarakat aghniya \\
\hline 4 & $\begin{array}{l}\text { Evaluasi dan } \\
\text { Pelaporan }\end{array}$ & $\begin{array}{l}\text { - Mengevaluasi kinerja Bidang } \\
\text { Pengumpulan } \\
\text { - Membuat laporan }\end{array}$ & $\begin{array}{l}\text { - Intensifikasi dan } \\
\text { ekstensifikasi } \\
\text { - Kualitas dan } \\
\text { kuantitas kinerja } \\
\text { BAZ }\end{array}$ & $\begin{array}{l}\text { Meningkatnya } \\
\text { kinerja BAZ } \\
\text { khususnya Bidang } \\
\text { pengumpulan }\end{array}$ \\
\hline
\end{tabular}

TABEL 4.5

\begin{tabular}{|c|c|c|c|c|}
\hline NO & PROGRAM & URAIAN KEGIATAN & SASARAN & $\begin{array}{l}\text { TARGET YANG INGIN } \\
\text { DICAPAI }\end{array}$ \\
\hline 1 & $\begin{array}{l}\text { Optimalisasi } \\
\text { pelayanan } \\
\text { pendistribusian } \\
\text { dana zakat }\end{array}$ & $\begin{array}{l}\text { - Menyeleksi surat } \\
\text { permohonan/proposal para } \\
\text { mustahiq } \\
\text { - Melaksanakan pengecekan } \\
\text { langsung kepada calon penerima } \\
\text { bantuan yang keberadaannya } \\
\text { diragukan } \\
\text { - Bekerjasama dengan BAZ } \\
\text { kecamatan }\end{array}$ & $\begin{array}{l}\text { Setiap permohonan, baik } \\
\text { perorangan maupun } \\
\text { kolektif }\end{array}$ & $\begin{array}{l}\text { - Sesuai dengan } \\
\text { kebutuhan dan hasil } \\
\text { rapat } \\
\text { - Ada jadwal jelas } \\
\text { (periodisasi) } \\
\text { - Keakuratan data }\end{array}$ \\
\hline 2 & $\begin{array}{l}\text { Pendistribusian rutin } \\
\text { pada acara hari } \\
\text { besar nasional, hari } \\
\text { besar Islam dan hari } \\
\text { jadi Kota Bandung }\end{array}$ & $\begin{array}{l}\text { - Menerima menyeleksi surat } \\
\text { permohonan/proposal para } \\
\text { mustahiq } \\
\text { - Melaksanakan koordinasi dengan } \\
\text { bidang dan dinas/instansi terkait } \\
\text { - Menyiapkan daftar penerima } \\
\text { bantuan }\end{array}$ & $\begin{array}{l}\text { Para siswa-siswi yang } \\
\text { tidak mampu, tenaga } \\
\text { kontrak, guru honor, } \\
\text { petugas kebersihan, guru } \\
\text { agama, guru ngaji, } \\
\text { sukarelawan dan usulan } \\
\text { dari UPZ dinas/instansi }\end{array}$ & $\begin{array}{l}\text { Sesuai kebutuhan dan } \\
\text { hasil rapat }\end{array}$ \\
\hline 3 & $\begin{array}{l}\text { Melaksanakan } \\
\text { pendistribusian } \\
\text { kepada para } \\
\text { mustahiq yang } \\
\text { dating ke sekretariat } \\
\text { BAZ Kota Bandung } \\
\end{array}$ & $\begin{array}{l}\text { - Menerima, menyeleksi surat } \\
\text { permohonan/proposal para } \\
\text { mustahiq } \\
\text { - Melaksanakan koordinasi dengan } \\
\text { bidang dan dinas/instansi terkait }\end{array}$ & $\begin{array}{l}\text { - Setiap permohonan, } \\
\text { baik perorangan } \\
\text { maupun kolektif } \\
\text { - Bantuan dana sertifikasi } \\
\text { tanah wakaf }\end{array}$ & $\begin{array}{l}\text { - Sesuai dengan } \\
\text { kebutuhan dan hasil } \\
\text { rapat BAZ yang sudah } \\
\text { disepakati } \\
\text { - Sesuai dengan } \\
\text { anggaran BAZ }\end{array}$ \\
\hline
\end{tabular}


kondisi kemiskinan di Kota Bandung. Seperti yang telah disebutkan sebelumnya bahwa jumlah masyarakat miskin di wilayah ini adalah sebesar 116.904 jiwa atau 4,78\% dari total penduduk Kota Bandung. Analisis tentang kondisi tersebut maka BAZ Kota Bandung memberikan dana bergulir berupa bantuan modal usaha untuk peningkatan kesejahteraan para mustahik ataupun para pedagang kecil melalui penghasilan yang layak. Pendayagunaan zakat harus berdampak positif bagi mustahik baik secara ekonomi maupun sosial. Dari sisi ekonomi, mustahik dituntut benar-benar dapat mandiri dan hidup secara layak, sedangkan dari sisi sosial, mustahik dituntut dapat hidup sejajar dengan masyarakat miskin yang lain. Kelemahan utama orang miskin serta usaha yang dijalankannya adalah dari segi permodalan. Zakat yang dapat dihimpun dalam jangka panjang harus dapat memberdayakan mustahik sampai pada dataran pengembangan usaha.

Dana bergulir merupakan salah satu wujud program pemberdayaan, dengan tujuan menguatkan ekonomi kelompok miskin dengan melibatkan mereka dalam program dibidang ekonomi agar mampu keluar dari kemiskinan. Bentuk program umumnya adalah introduksi penguatan program usaha bagi kelompok miskin dalam bentuk modal pembiayaan kebajikan (qardhul hasan). Konsepnya, kelompok miskin diberi pinjaman dana usaha yang besarnya disesuaikan dengan kebutuhan usahanya, kemudian si penerima tadi mengembalikan dalam waktu tertentu hanya senilai pokoknya saja dari dana yang diberikan oleh BAZ, tanpa tambahan atau biaya apapun. Dana bergulir merupakan salah satu program kerja Bidang Pendayagunaan BAZ Kota Bandung.
Program dana bergulir BAZ Kota Bandung telah diimplementasikan di wilayah Kota Bandung selama kurang lebih 3 tahun sejak tahun 2010. dan selama itu pula telah banyak kelompok miskin yang mengikuti program ini. Tentu saja salah satu indikator keberhasilan program ini adalah peningkatan kualitas ekonomi peserta program. Implementasi program dana bergulir BAZ di Kota Bandung dapat memberikan gambaran bagaimana kebijakan yang telah dibuat oleh BAZ Kota Bandung dalam rangka menanggulangi kemiskinan. Masalah kemiskinan merupakan salah satu masalah penting yang harus ditanggulangi oleh pemerintah dan BAZ sesuai dengan Quran dan UUD 1945. Dalam sasaran jangka panjang kedua sasaran ini ditegaskan kembali dengan menggaris bawahi terciptanya kualitas manusia dan kualitas masyarakat Indonesia yang maju dan mandiri. Tujuan dana bergulir diarahkan kepada upaya penanggulangan kemiskinan, melalui peningkatan pendapatan dan pengembangan usaha. Sasaran penerima manfaat program penanggulangan kemiskinan di Kota Bandung melalui dana bergulir BAZ adalah kelompok warga masyarakat/keluarga sangat miskin/fakir miskin, miskin, dan hampir miskin sesuai kategori Badan Pusat Statistik (BPS), dengan skala prioritas bagi keluarga sangat miskin dan miskin.

Penerima dana bergulir ditetapkan dengan kriteria sebagai berikut: Kepala keluarga dan/ atau pencari nafkah utama dalam keluarga yang masuk kategori miskin dan sangat miskin; Berdomisili tetap; Berusia minimal 18 tahun dan maksimal 60 tahun; Memiliki potensi dan keterampilan di bidang usaha ekonomi tertentu. Calon penerima dana bergulir diharuskan mengajukan usulan 
usaha yang menggambarkan alasan dan prospek pengembangan usaha, seperti gambaran usaha berisi tentang gambaran detail rencana usaha meliputi jenis usaha, aspek produksi, aspek pemasaran, aspek kebutuhan, dan hal lain yang dibutuhkan, serta analisa keuangan berisi tentang perhitungan keuangan usaha untuk pemodalan (biaya produksi, pemasaran, dll) dilengkapi dengan estimasi harga jual dan keuntungan.

BAZ Kota Bandung bekerjasama dengan BAZ Kecamatan di Kota Bandung dalam melaksanakan program dana bergulir di Kota Bandung. Pelaksanaan program dana bergulir diawali dengan pemanggilan ketua BAZ Kecamatan di tiap kecamatan Kota Bandung untuk rapat koordinasi penyaluran dana bergulir oleh BAZ Kota Bandung. BAZ Kecamatan bertugas untuk mensosialisasikan dana bergulir di masing-masing wilayahnya.

Dan merekomendasikan mustahik yang layak diberi dana bergulir kepada BAZ Kota Bandung. Tidak semua orang yang direkomendasikan oleh BAZ Kecamatan merupakan warga miskin atau sangat miskin, tetapi sudah ditetapkan per kecamatan diberikan dana bergulir sebesar 5.000.000 rupiah untuk 10 orang pemohon dana bergulir, masing-masing sebesar 500.000 rupiah. Penerima dana bergulir menyerahkan cicilan selama 10 - 12 bulan tanpa biaya atau tambahan apapun kepada BAZ dari masingmasing kecamatan.

Setiap kecamatan memiliki BAZ dan UPZ yang akan membantu dalam keberlangsungan usaha penerima dana bergulir serta sebagai usaha monitoring dari BAZ Kota Bandung. Namun tidak setiap penerima dana bergulir bisa ditangani oleh BAZ Kecamatannya karena kurangnya intensitas komunikasi yang dilakukan antar BAZ kecamatan dan penerima dana bergulir. Kegiatan pendampingan juga sampai saat ini belum mencakup kegiatan peningkatan skill dan kreatifitas para penerima dana bergulir. Kegiatan pendampingan hanya mencakup memberikan saran dan masukan ketika penerima dana bergulir kesulitan. Mekanisme program dana bergulir dijalankan berdasarkan keputusan BAZ Kota Bandung. Mekanisme penyaluran dana bergulir dilakukan dari BAZ Kota Bandung menggunakan dana zakat. Dana tersebut kemudian diberikan kepada BAZ di setiap kecamatan di Kota Bandung untuk disalurkan ke kelurahan-kelurahan.

Untuk mengetahui bagaimana pelaksanaan program ini berdasarkan teori maka analisis akan dilakukan menggunakan teori dari Edward III. Teori tersebut menyatakan tentang model Implementasi Kebijakan Publik. Teori ini menyatakan bahwa ada empat variabel yang berperan penting dalam pencapaian keberhasilan implementasi, yaitu komunikasi (communication), sumber daya (resources), disposisi (dispotition), dan struktur birokrasi (bureaucratic structures). Keempat variabel tersebut memiliki keterkaitan satu dengan yang lain dalam mencapai tujuan dan sasaran program atau kebijakan. Semuanya saling bersinergi dalam mencapai tujuan dan satu variabel akan mempengaruhi variabel yang lain.

\section{Komunikasi}

Komunikasi dalam implementasi program dana bergulir BAZ Kota Bandung dilakukan pada saat sosialisasi, pengumpulan berkas pemohon dana bergulir maupun dalam pencairan dana bergulir. Sosialisasi program dana bergulir dilaksanakan di sekretariat 
BAZ Kota Bandung. Strategi yang digunakan untuk memudahkan sosialisasi dari BAZ Kota Bandung adalah dengan mengundang BAZ di tiap kecamatan di Kota Bandung. Sosialisasi tidak berhenti hanya di tingkat BAZ Kota Bandung. Sosialisasi dilaksanakan sampai tingkat kecamatan dan kelurahan.

Dalam penyampaian informasi, pelaksanaan sosialisasi program dana bergulir dari BAZ Kota Bandung dan BAZ kecamatan hanya menggunakan media surat dan lisan. Sedangkan dari tingkat kelurahan nya hanya melalui lisan kepada warga. Para pelaksana program dana bergulir senantiasa menyampaikan kepada para penerima dana bergulir bahwa dana begulir BAZ Kota Bandung walaupun merupakan dana hibah, tetapi dana yang ada harus digulirkan untuk modal usaha, karenanya diharuskan membayar cicilan perbulan semampunya tanpa ada tambahan atau biaya apapun, dengan tujuan meningkatkan modal sehingga bisa meningkatkan pendapatan. Pelaksanaan program dana bergulir sejak 2010 hingga 2012 belum begitu berjalan baik, misalnya sosialisasi yang dilakukan belum optimal, kebanyakan hanya sebatas pada daerah yang terdekat dari rumah pribadi UPZ atau orang yang telah dikenal oleh UPZ.

Pelaksanaan program dana bergulir di lapangan tidak sepenuhnya berjalan sesuai yang direncanakan. Banyak penerima dana bergulir yang tidak mengembalikan dana bergulir tersebut kepada pihak BAZ Kecamatan, karena tidak adanya komunikasi dan koordinasi antara BAZ Kecamatan, UPZ dan penerima dana bergulir setelah dana bergulir itu dicairkan. Seperti yang diutarakan salah satu penerima program dana bergulir dari Kecamatan Bojongloa Kaler, seorang pedagang gorengan, Ibu
Wisah:

"Saya sempet setor tiga kali. Tapi karena ibuibu (penerima dana bergulir) yang lain tidak pada setor, akhirnya saya tidak setor juga. Tidak ada yang datang juga dari BAZ nya. Tadinya kan saya berharap kalo yang ini lunas, saya bisa dikasih lagi modal yang lebih besar".

Hal ini menyimpang dari rencana disalurkannya dana bergulir agar adanya pemantauan modal usaha melalui pelaporan terkendali sehingga menciptakan mustahik yang produktif. Penyimpangan ini terjadi karena para penerima dana bergulir tidak mendapatkan bimbingan ataupun koordinasi dari BAZ Kecamatan untuk pengembalian dana bergulir sehingga mereka tidak ada motivasi untuk mengembalikan. Selain itu, karena tidak adanya pemantauan intensif dari BAZ Kota Bandung kepada BAZ Kecamatan, berpengaruh pula dari BAZ Kecamatan kepada penerima dana bergulir, sehingga penerima dana bergulir tidak mendapatkan informasi terbaru dari BAZ Kecamatan.

\section{Sumber daya}

Sumber daya dalam pelaksanaan program dana bergulir BAZ Kota Bandung dari sisi staf memiliki kemampuan yang cukup baik dan jumlahnya memadai. Dikarenakan untuk menginformasikan program dana bergulir langsung kepada mustahik sendiri pihak BAZ Kota Bandung menyerahkan pada BAZ Kecamatan. Begitupun dalam hal tanggung jawab pengelolaan dana bergulir diserahkan langsung kepada pihak BAZ Kecamatan. Pelaksana teknis program dana bergulir sendiri adalah staf sekretariat BAZ Kota Bandung, dikarenakan anggota di Bidang 
Pendayagunaan ini lebih fokus kepada penyusunan program dan evaluasi hasil dari teknis di lapangan. Staf sekretariat sendiri membantu dalam hal proses administrasi, pengecekkan kelengkapan persyaratan pemohon dana bergulir, pengentryan data begitupun ketika pencairan yang diserahkan melalui BAZ Kecamatan ataupun langsung ke penerima dana bergulirnya. Tingkat pendidikan para pelaksana program dana bergulir BAZ Kota Bandung cukup baik yaitu minimal SMU. Dari 13 orang staf, 10 orang berpendidikan S1 dan 2 orang berpendidikan S2. Tingkat pendidikan ini juga dibarengi dengan tingkat keterampilan yang cukup karena hampir semua sudah terampil menggunakan komputer. Dari sisi wewenang, maka ketepatan dan efektifitas pelimpahan wewenang pelaksana sudah cukup baik.

Fasilitas yang dibutuhkan dalam pelaksanaan program dana bergulir adalah sarana dan pra sarana. Sarana dan pra sarana yang dimiliki BAZ Kota Bandung antara lain ruang kerja, komputer sebanyak 3 unit, printer 2 unit, faximile, telpon, mesin penghancur kertas, dan sejumlah ATK. Pada saat observasi, peneliti menjumpai tidak ada tempat pemberkasan tersendiri untuk program dana bergulir. Kalaupun ada tempat pemberkasan, semua berkas ditumpuk di lemari berkas sehingga terkesan penuh dan sangat tidak rapi. Hal itu tentu saja mempengaruhi kenyamanan para staf dalam melaksanakan pekerjaannya. Begitupun untuk koneksi internet, baru dipasang enam bulan terakhir. Padahal internet merupakan media yang sangat penting untuk sekarang ini, internet bisa mempermudah surat menyurat melalui email dan mempermudah koordinasi data antar BAZ Kecamatan, ataupun untuk menginformasikan data dan berita terbaru dari BAZ kota. Sedangkan sarana dan pra sarana di hampir semua BAZ kecamatan kurang memadai. Kebanyakan sekretariat BAZ kecamatan bertempat di KUA.

\section{Disposisi Implementor}

Suatu kebijakan akan berhasil secara efektif dan efisien jika para pelaksana kebijakan tidak hanya mengetahui apa yang harus mereka lakukan dan mempunyai kemampuan untuk implementasi kebijakan tersebut, tetapi mereka juga harus mempunyai kemauan untuk mengimplementasikan kebijakan tersebut. Sikap para pelaksana program dana bergulir cukup baik dan mendukung sebagaimana diungkapkan oleh ketua BAZ Kota Bandung. Hal ini diakui juga oleh salah satu penerima program dana bergulir dari kecamatan Andir, yang membuka usaha warung kopi. Begitupula menurut pengakuan salah satu penerima dana bergulir dari kecamatan Astana Anyar, yang membuka usaha tambal ban. Permasalahan terjadi ketika dana sudah dicairkan dan diberikan kepada pihak penerima dana bergulir. Hasil penelitian menunjukkan bahwa tidak adanya pendampingan kepada para penerima dana bergulir. Begitu juga tidak adanya pelatihan untuk para BAZ kecamatan dan UPZ dalam hal pendampingan. Pelatihan hanya berupa sosialisasi. Dampaknya komitmen BAZ kecamatan menjadi kurang maksimal dalam pengelolaan dana bergulir. Hal ini bisa dilihat dari jumlah BAZ kecamatan yang aktif dalam pengelolaan dana bergulir hanya 5 kecamatan dari 30 kecamatan yang ada.

\section{Struktur Birokrasi}

Pelaksanaan program dana bergulir di 
BAZ Kota Bandung ini didukung oleh efektifitas struktur organisasi yang baik. Ketua dan semua staf terlibat dan mempunyai andil yang proporsional. Pembagian kerja berjalan baik sehingga mampu menyelesaikan tanggung jawabnya sesuai yang dijadwalkan. Keterlibatan semua komponen ini juga merupakan syarat keberhasilan implementasi kebijakan program dana bergulir. Koordinasi internal yaitu dalam pelaksanaan teknis program dana bergulir di sekretariatan BAZ Kota Bandung berjalan baik. Begitu juga dengan koordinasi eksternal BAZ Kota Bandung dengan BAZ Kecamatan, ataupun UPZ. Kesatuan perintah berjalan sesuai yang diharapkan dengan mengacu pada struktur organisasi pelaksana program dana bergulir. Jika dalam pelaksanaan program dana bergulir menemui masalah maka para pelaksana teknis dana bergulir bisa konsultasi langsung ke BAZ kota.

\section{Badan Amil Zakat, Implementasi Kebijakan Publik dan Penanggulangan Kemiskinan}

Implikasi zakat dalam perekonomian, yaitu: Pertama, zakat dapat memenuhi kebutuhan masyarakat yang kekurangan. Kedua, zakat memperkecil jurang kesenjangan ekonomi. Ketiga, zakat dapat menekan jumlah permasalahan sosial, kriminalitas, pelacuran, gelandangan, pengemis dan lain-lain. Keempat, zakat dapat menjaga kemampuan beli masyarakat agar dapat memelihara sektor usaha. Dengan kata lain zakat menjaga konsumsi masyarakat pada tingkat yang minimal, sehingga perekonomian dapat terus berjalan. Ketua Umum Badan Amil Zakat Nasional (Baznas) Didin Hafidhuddin menyitir hasil penelitian
Baznas bersama Fakultas Ekonomi dan Manajemen Institut Pertanian Bogor. Potensi dana zakat, infak, dan shadaqah (ZIS) mencapai 217 triliun. Nilai itu setara dengan 20\% Anggaran Pendapatan Belanja Negara (APBN). Yang mana, potensi besar zakat itu belum tercermin dalam realitas pengumpulan ZIS, yang mana jumlah penghimpunan zakat dari seluruh LAZ di Indonesia tahun 2011 sekitar Rp. 1,7 triliun. Sedang penerima manfaat melalui program penyaluran dana zakat (mustahik) sebanyak 1,7 juta orang. Dana yang terkumpul itu meningkat 15,33\% dari tahun 2010. Apabila mengacu pada penelitian Baznas di atas, dana yang terkumpul itu baru $1 \%$ dari potensi zakat di Indonesia.

Penghimpunan zakat di BAZ Kota Bandung sendiri, sebagian besar bersumber dari zakat para pegawai di lingkungan pemkot Bandung dan Kementrian Agama Kantor Kota Bandung. Yang mana zakat yang dibebankan kepada PNS itu disebut infak wajib profesi, sesuai dengan Surat Perintah Walikota No. 451.12/SE.056-PEG tahun 2004 tentang Pelaksanaan Zakat Profesi Untuk Pejabat Eselon II sampai dengan IV di Lingkungan Pemkot, dan sesuai dengan Surat Edaran Walikota No. 451.12/SE.056-KESRA tahun 2006 tentang Pengumpulan Zakat, Infaq dan Sadaqah/Zakat Profesi. Adapun potensi yang sudah dilaksanakan oleh BAZ Kota Bandung sampai dengan tahun 2011 baru 6.631 pegawai ( $\pm 23 \%$ ) dari 28.352 pegawai di lingkungan Pemkot Bandung dan Kementerian Agama kantor Kota Bandung. Yang mana masih banyak Satuan Kerja Perangkat Daerah (SKPD) yang belum melaksanakan atau mensosialisasikan.

Kemiskinan yang berkaitan dengan kebijakan ekonomi negara atau kawasan, 
berkorelasi struktural. Kemiskinan struktural yaitu kemiskinan yang terjadi sebagai akibat ketidakberdayaan seseorang atau sekelompok masyarakat tertentu terhadap sistem atau tatanan sosial yang tidak adil, karenanya mereka pada posisi tawar yang sangat lemah dan tidak memiliki akses untuk mengembangkan dan membebaskan diri mereka sendiri dari perangkap kemiskinan. Di negara-negara berkembang, kemiskinan sangat terkait dengan aspek struktural.

Misalnya, akibat sistem ekonomi yang tidak adil, merajalelanya KKN (Korupsi, Kolusi dan Nepotisme), adanya diskriminasi sosial, atau tidak adanya jaminan sosial. Sehingga cukup jelas bahwa strategi dalam penanggulangan kemiskinan hendaknya diarahkan bukan saja pada orang miskinnya. Melainkan pula pada faktor-faktor di luar dirinya yang mempengaruhi kehidupan orang miskin. Dana bergulir, yang merupakan pinjaman modal usaha dari BAZ Kota Bandung, adalah salah satu strategi kebijakan publik dalam penanggulangan kemiskinan yang berbasis peningkatan ekonomi masyarakat miskin. Kebijakan program dana bergulir terutama bagi kelompok miskin yang telah direkomendasikan untuk dipilih oleh policy maker bukanlah jaminan bahwa kebijakan tersebut pasti berhasil dalam

implementasinya.

Keberhasilan implementasi program dana bergulir BAZ di Kota Bandung ditentukan oleh banyak faktor dan masing-masing faktor tersebut saling berhubungan satu sama lain. Dalam pandangan beberapa ahli maka implementasi kebijakan dipengaruhi oleh banyak faktor. Dalam penelitian ini faktor yang mempengaruhi implementasi kebijakan program dana bergulir di Kota Bandung adalah: 1) Komunikasi; 2) sumber daya; 3) disposisi; dan 4) struktur birokrasi, dan 5) kondisi sosial ekonomi. Pertama, komunikasi. Keberhasilan implementasi kebijakan mengisyaratkan agar implementor mengetahui apa yang harus dilakukan. Apa yang menjadi tujuan dan sasaran kebijakan harus ditransmisikan kepada kelompok sasaran (target group) sehingga akan mengurangi distorsi implementasi. Apabila tujuan dan sasaran suatu kebijakan tidak jelas atau bahkan tidak diketahui sama sekali oleh kelompok sasaran.

Kedua, sumber daya. Walaupun isi kebijakan sudah dikomunikasikan secara jelas dan konsisten, tetapi apabila implementor kekurangan sumber daya untuk melaksanakan, implementasi tidak akan berjalan efektif. Sumber daya tersebut dapat berwujud sumber daya manusia, yakni kompetensi implementor, dan sumber daya finansial. Sumber daya adalah faktor penting untuk implementasi kebijakan yang efektif. Tanpa sumber daya kebijakan hanya tinggal di kertas menjadi dokumen. Ketiga, disposisi. Disposisi adalah watak dan karakteristik yang dimiliki oleh implementor, seperti komitmen dan kejujuran. Apabila implementor memiliki disposisi yang baik, maka dia akan dapat menjalankan kebijakan dengan baik seperti apa yang diinginkan oleh para pembuat kebijakan. Ketika implementor memiliki sikap atau perspektif yang berbeda dengan pembuat kebijakan, maka proses implementasi kebijakan juga menjadi tidak efektif. Keempat, struktur birokrasi. Struktur organisasi yang mengimplementasi kebijakan memiliki pengaruh yang signifikan terhadap implementasi kebijakan. Struktur birokrasi yang terlalu panjang akan cenderung melemahkan pengawasan dan menimbulkan red-tape, yakni prosedur birokrasi yang rumit 
dan kompleks. Ini pada gilirannya akan menyebabkan aktivitas organisasi tidak fleksibel.

\section{Hambatan Implementasi Kebijakan Pro- gram Dana Bergulir}

Faktor pertama yang mempengaruhi implementasi program dana bergulir di BAZ Kota Bandung adalah komunikasi. Faktor ini meliputi transmisi, konsistensi, dan kejelasan. Informasi tentang program dana bergulir harus diteruskan kepada BAZ kecamatan dan kelompok miskin. Tentu saja komunikasi harus akurat dan harus dimengerti.

Keakuratan informasi ini menjadi hal mutlak yang harus dikuasai oleh para personil pelaksana program karena mereka harus menyampaikan kembali kepada sasaran kebijakan program dana bergulir ini yaitu kelompok miskin dan pedagang kecil.

Konsistensi dalam komunikasi program dana bergulir merupakan aspek yang menjadi permasalahan. Komunikasi program dari pihak BAZ kota belum optimal kepada pihak BAZ kecamatan. Pihak BAZ kecamatan sendiri belum mampu menjaga kekonsistenan informasi dan koordinasi pada pihak UPZ dan penerima dana bergulir. Indikatornya bisa dilihat dari $30 \mathrm{BAZ}$ kecamatan di Bandung, yang aktif koordinasi dan pelaporan pengelolaan dalam program dana bergulir hanya 5 Kecamatan, yaitu Kecamatan Cicendo, kecamatan Buah Batu, kecamatan Mandalajati, kecamatan Kiara condong, dan kecamatan Cibeunying Kaler.

Van Meter dan Horn menjelaskan bahwa implementasi kebijakan perlu dukungan sumber daya baik sumberdaya manusia maupun sumberdaya non-manusia. Faktor sumberdaya sebagai satu penentu keberhasilan implementasi program dana bergulir BAZ Kota Bandung. Faktor ini meliputi staf, informasi, wewenang dan fasilitas. Kurang terpenuhinya sumber-sumber ini berarti ketentuan-ketentuan atau aturanaturan tidak menjadi kuat, pelayanan tidak akan diberikan dan pengaturan yang rasional tidak dapat dikembangkan. Hal lain yang harus ada dalam sumber daya adalah kewenangan untuk menjamin atau meyakinkan bahwa kebijakan yang diimplementasikan adalah sesuai dengan yang mereka kehendaki. Dalam pelaksanaan program dana bergulir BAZ di Kota Bandung, ketua BAZ Kota Bandung mampu menjalankan wewenang secara efektif. Menurut Edward, para pejabat dari yuridiksi tingkat tinggi dalam menangani implementasi biasanya meminta bantuan pejabat-pejabat yuridiksi tingkat rendah. Para pejabat pada tingkat yuridiksi yang lebih tinggi sering meminta pandangan (sharing) kepada pejabat di tingkat yang lebih rendah atau para pelaksana tentang bagaimana mengimplementasikan kebijakan. Dengan cara seperti ini setidaknya ada dua keuntungan yang dapat diraih, pertama mendorong keterlibatan para pelaksana kebijakan sehingga pada akhirnya akan mendorong partisipasi.

Kedua, mengeliminasi penolakan yang mungkin timbul dari para pelaksana kebijakan. Minimal, para pelaksana kebijakan memberikan apa yang diminta oleh para perumus kebijakan. Hal ini terjadi pada implementasi program dana bergulir BAZ Kota Bandung. Pihak BAZ Kota Bandung melibatkan BAZ Kecamatan dan UPZ untuk membantu dalam pelaksanaan program dana bergulir ini. Selain itu, baik BAZ Kecamatan maupun UPZ diminta membantu pemohon dana bergulir dalam 
hal pengisian dan kelengkapan berkas administrasi permohonan. Peran aktif BAZ kecamatan dan UPZ tentu saja sangat dibutuhkan dalam program ini. Karena pengelolaan dana bergulir ini secara otomatis menjadi tanggung jawab BAZ kecamatan. Karena itulah mereka pun harus melaksanakan survey dan merekomendasikan mustahik yang layak diberi dana bergulir. Yang tidak kalah pentingnya adalah kemauan BAZ kecamatan dan UPZ untuk berperan aktif membantu para penerima program dana bergulir dan kemauan mereka untuk mengelola dana bergulir.

Komponen keempat dalam sumber daya adalah fasilitas. Menurut Edwards, fasilitas fisik merupakan sumber penting dalam implementasi. Seorang pelaksana mungkin mempunyai staf yang memadai, mungkin memahami apa yang dilakukan, dan mungkin mempunyai wewenang untuk melakukan tugasnya, tetapi tanpa bangunan sebagai kantor untuk melakukan koordinasi, tanpa perlengkapan, tanpa perbekalan, maka besar kemungkinan implementasi yang direncanakan tidak akan berhasil.

Komponen fasilitas dalam pelaksanaan implementasi program dana bergulir BAZ di Kota Bandung secara keseluruhan termasuk tidak memadai. Untuk fasilitas di sekretariat BAZ Kota Bandung bisa dibilang cukup memadai, sedangkan hampir semua BAZ kecamatan di Kota Bandung tidak mempunyai fasilitas fisik ruangan atau kantor

Disposisi implementor atau kecenderungan pelaksana merupakan faktor ketiga dalam implementasi kebijakan yang mempunyai konsekuensi penting bagi implementasi kebijakan yang efektif. Menurut Edwards, terkait disposisi implementor, ada kebijakan yang dilaksanakan secara efektif, namun kebijakan-kebijakan lain mungkin akan bertentangan secara langsung dengan pandangan-pandangan pelaksana kebijakan atau kepentingan-kepentingan pribadi atau organisasi dari para pelaksana. Dalam implementasi program dana bergulir BAZ Kota Bandung ini, kecenderungan implementor meliputi sikap pelaksana, tingkat kepatuhan pelaksana, dan komitmen dari pelaksana. Secara umum kecenderungan implementor belum begitu baik. Para pelaksana program belum memiliki sikap dan atau perspektif yang mendukung kebijakan. Indikatornya adalah tidak adanya keaktifan BAZ kecamatan untuk pelaporan dana bergulir dikarenakan komitmen dari BAZ kecamatan yang kurang.

Struktur birokrasi organisasi yang mengimplementasikan kebijakan memiliki pengaruh yang signifikan terhadap implementasi kebijakan. Salah satu dari aspek struktur yang penting dari setiap organisasi adalah adanya prosedur operasi standar (Standard Operating Procedures/SOP) yang menjadi pedoman bagi implementor di dalam bertindak. Struktur organisasi dalam pelaksanaan program dana bergulir BAZ Kota Bandung meliputi efektifitas struktur organisasi, pembagian kerja, koordinasi, dan standar keberhasilan. Sedangkan SOP untuk para pelaksana program dana bergulir BAZ Kota Bandung tidak ada acuan baku yang tertulis, hanya secara teknis ada. Sehingga tidak adanya pembagian tanggung jawab yang tegas di antara personil. Sedangkan untuk menjamin pelaksanaan pekerjaan harus dilakukan pembagian kerja dan dibarengi dengan pengawasan yang efektif.

\section{KESIMPULAN}

Implementasi program dana bergulir 
dilakukan dengan memberikan modal usaha dan pendampingan. Program ini disertai dengan pendampingan oleh BAZ kecamatan dan UPZ, sehingga dana bergulir langsung dikelola dan betul-betul digulirkan untuk modal usaha, sehingga usaha penerima dana bergulir bisa berkelanjutan dan berkembang dengan optimal. Keberadaan BAZ kecamatan sebagai pendamping merupakan salah satu faktor yang sangat menentukan keberhasilan program penanggulangan kemiskinan melalui dana bergulir. Pendamping memiliki peranan yang strategis, yakni sebagai narasumber, penggerak sekaligus sebagai fasilitator bagi pemberdayaan keluarga miskin. Sudah barang tentu untuk dapat melaksanakan tugas yang cukup berat tersebut para pendamping harus memiliki pengetahuan dan kemampuan yang memadai. Pelaksanaan program dana bergulir BAZ Kota Bandung mulai dilaksanakan pada tahun 2010. Sejak tahun itu, jumlah penerima dana bergulir meningkat seiring dengan adanya sosialisasi dari BAZ Kota Bandung melalui BAZ di tiap kecamatan.

Hambatan dari implementasi kebijakan program dana bergulir ini adalah minimnya komunikasi dua arah antara BAZ kota dengan BAZ kecamatan, sehingga tidak adanya koordinasi yang berkelanjutan, yang menyebabkan tidak adanya komitmen dan motivasi dari pihak BAZ kecamatan untuk mengelola dana bergulir dan membimbing penerima dana bergulir di daerahnya. Hal ini berpengaruh pula pada penerima dana bergulir karena merasa tidak diawasi sehingga perkembangan tidak baik.

Oleh karena itu, berdasarkan hasil penelitian di atas, maka penulis dapat memberikan saran sebagai berikut: BAZ kecamatan sebaiknya berhubungan baik dengan BAZ kota sehingga sinergi diantara keduanya dapat berkelanjutan dan berkembang. Hal ini diharapkan sangat membantu di dalam pengelolaan dana bergulir. Pelaksanaan sosialisasi program ini harus disampaikan kepada seluruh masyarakat yang ada di lingkungan program yang akan diberikan, sehingga mayarakat dapat mengetahui program yang diluncurkan. Sosialisasi program harus dilakukan terhadap beberapa kelompok sasaran, seperti: lurah, tokoh masyarakat, warga secara umum, dan terutama kelompok calon sasaran. Pendampingan terhadap para penerima dana bergulir perlu diadakan. Begitu pula harus adanya pelatihan untuk pendamping, dalam hal ini pihak BAZ kecamatan sehingga ketika melakukan pendampingan dilaksanakan secara professional. Mulai dari bagaimana manajemen pengelolaan dana bergulir, pengembangan jenis usaha, pengguliran, supervisi dan evaluasi. Selain itu, pengembangan komitmen dari BAZ kecamatan dan UPZ juga menjadi hal yang sangat penting.

\section{CATATAN AKHIR}

http://jabar.bps.go.id/node/63

2 A. Rahman Zainuddin, Zakat: Implikasinya Pada Pemerataan, dalam Nurcholis Madjid, Kontekstualisasi Doktrin Islam Dalam Sejarah (Jakarta: Paramadina, 1994), h. 437.

3 Didin Hafidhuddin, Agar Harta Berkah Dan Bertambah (Jakarta: Gema Insani, 2007), h.69.

4 Abdurrahman Oadir, Zakat Dalam Dimensi Mahdah dan Sosial (Jakarta: RajaGrafindo Persada, 2001)

Al-Quran, surat Al-Baqarah ayat 219.

Al-Quran, surat Al-Hasyr ayat 7.

Abdurrahman Oadir, Zakat Dalam Dimensi Mahdah Dan Sosial, (Jakarta: Raja Grafindo Persada, 2001)

8 HM. Djamal Doa, Pengelolaan Zakat Oleh Negara, (Jakarta: Nuansa Madani, 2004), h. 80; lihat Hilman Latief, "Contesting Almsgiving in Post New Order Indonesia," American Journal of Islamic Social Sciences, 
Vol. 31, No. 1 (Winter 2014), pp. 16-50; juga Hilman Latief, Politik Filantropi Islam di Indonesia: Negara, Pasar, dan Masyarakat Sipil (Yogyakarta: Ombak, 2013).

9 Sutoro Eko, 'Desentralisasi dan Penanggulangan Kemiskinan', dalam A. Prasetyantoko (eds.), Pembangunan Inklusif: Prospek dan Tantangan Indonesia (LP3ES, Jakarta, 2012), h. 352.

10 Deswanto Marbun dan Asep Suryahadi, "Kriteria Kemiskinan Konsumsi: Praktik di Indonesia dan Beberapa Catatan", Jurnal Analisis Sosial, Volume 14, 2 (September, 2009), h. 14.

11 Sidi Gazalba, Ilmu Islam: Asas Agama Islam, (Cet 2; Jakarta: PT. Bulan Bintang, 1985), h. 134.

12 Teungku Hasby Ash-Shiddieqie, Pedoman Zakat, (Semarang: PT. Pustaka Rizki Putra, 2006), h. 166.

13 http://media.isnet.org/islam/Quraish/Wawasan/ Miskin.html

14 Yusuf Oardhawi, Norma dan Etika Islam, (Jakarta: Gema Insani Press, 1997), h. 15 - 20.

15 Quraisy Shihab, Wawasan Al-Qur'an, (Jakarta: Mizan, 1989), h. 26.

16 UUD 1945 pasal 34 menegaskan bahwa kemiskinan merupakan tanggung jawab negara untuk menanggulanginya: "fakir miskin dan anak-anak terlantar dipelihara oleh negara."

\section{DAFTAR PUSTAKA}

Al-Oasim, Abu 'Ubaid. 2006. Ensiklopedia Keuangan Publik. Diterjemahkan oleh: Setiawan Budi Utomo. Depok: Gema Insani.

Abdad, M. Zaidi. 2003. Lembaga Perekonomian Ummat di Dunia Islam. Bandung: Angkasa.

Abdurrahman, Maman. 2010. Menuju Bandung Kota Jasa Bermartabat: Bercermin Pada Nabi dan Sahabat. Bandung: Pemda Kota Bandung.

Ali Hasan, M. 2008. Zakat dan Infak: Salah Satu Solusi Mengatasi Problema Sosial di Indonesia. Jakarta: Kencana Prenada Media Group.

Bamualim, Chaider S. dkk. 2006. Islamic Philanthropy and Social Development. Jakarta: CSRC.

Bungin, Burhan. 2010. Penelitian Kualitatif. Jakarta: Kencana Prenada Media Grup.

Chapra, M. Umer. 2000. The Future of Economics: An Islamic Perspective. Leicester: The Islamic Foundation.

Damanhuri, Didin S. 2010. Ekonomi Politik dan Pembangunan: Teori, Kritik, dan Solusi bagi Indonesia dan Negara Sedang Berkembang. Bogor: IPB Press.

Daud Ali, Mohammad. 2006. Sistem Ekonomi Islam Zakat dan Wakaf. Jakarta: UI-Press.

Dye, Thomas R., 11978, Understanding Public policy, Prentice Hall, Inc., New jersey.

Faizal Noor, Henry. 2013. Ekonomi Publik: Ekonomi Untuk Kesejahteraan Rakyat. Padang: Akademia.

Edwards III, George C., 1980, Implementing Public policy, Congressional Quarterly Press, Washington.
Gilbert, Alan, dan Josef Gugler. 2007. Urbanisasi dan Kemiskinan di Dunia Ketiga, terj. Anshori dan Juanda. Yogyakarta: Tiara Wacana Yogya.

Grindle, Merilee S., Ed., 1980, Politics and Policy Implementation in The Third World, Princenton University Press, Princenton, New jersey.

Hadi Permono, Sjechul. 1995. Pemerintah Indonesia Sebagai Pengelola Zakat Jakarta: Pustaka Firdaus.

Hadi, Sutrisno. 2000. Metodologi Research, jilid I. Yogyakarta: Andi.

Hafidhuddin, Didin. 2007. Agar Harta Berkah \& Bertambah: Gerakan Membudayakan Zakat, Infak, Sedekah, dan Wakaf. Jakarta: Gema Insani.

- 2011. "Peran Strategis Organisasi Zakat dalam Menguatkan Zakat di Dunia," Al-Infaq: Jurnal Ekonomi Islam, Vol. 2, No. 1. Maret.

. 2012. Manajemen Zakat Indonesia. Jakarta: Forum Zakat (FOZ).

Hafidhuddin, Didin. 2012. Manajemen Zakat Indonesia. Jakarta: Forum Zakat (FOZ).

Hafidhuddin, Didin dan Rahmat Pramulya. 2008. Kaya Karena Berzakat. Jakarta: Raih Asa Sukses.

Hidayat, Yayat. 2008. Zakat Profesi Solusi Mengetaskan Kemiskinan. Bandung: Mulia Press.

Huda, Nurul, dan Ahmda Muti. 2011. Keuangan Publik Islami: Pendekatan Al-Kharaj. Bogor: Ghalia Indonesia.

Huda, Nurul, Agus Suprayogi, Hastomo Aji, Rika Andriyati, Achmad Aliyudin, Decky Mayricko Arbain, Restukanti Utami, dan Totok Harmoyo. 2012. Keuangan Publik Islami: Pendekatan Teoretis dan Sejarah. Jakarta: Kencana Prenada Media Grup.

Jones, Charles O., 1983, An introduction to the Study of Public Policy, Third edition, Brooks/Cole Publishing Company, Moterey, California.

Kusumanegara, Solahuddin. 2010. Model dan Aktor Dalam Proses Kebijakan Publik. Yogyakarta: Gava Media.

Latief, Hilman. 2010. Melayani Umat: Filantropi Islam dan Ideologi Kesejahteraan Kaum Modernis. Jakarta: Gramedia Pustaka Utama. 2013. Politik Filantropi Islam di Indonesia: Negara, Pasar, dan Masyarakat Sipil. Yogyakarta: Ombak.

2014. "Contesting Almsgiving in Post New Order Indonesia," American Journal of Islamic Social Sciences, Vol. 31, No. 1 (Winter 2014), pp. 16-50.

Malik Kamal bin As-Sayyid Salim, Abu dan bin Abdul Aziz bin Bazz, Abdullah. terj. Abu Ammar, 2010. Ensiklopedia Shaum \& Zakat: Penjelasan Lengkap dan Fatwa-fatwa Penting Seputar Hukum Shaum dan Zakat. Solo: Cordova Mediatama.

Mas'udi, Masdar Farid. 2005. Pajak Itu Zakat. Bandung: Mizan Media Utama.

Mawardi. 2005. "Strategi Efektifitas Peran Lembaga Zakat di Indonesia," Jurnal Hukum Islam. Vol. IV No. 2. Desember. 
Mhd. Ali, Nuruddin. 2006. Zakat Sebagai Instrumen Dalam Kebijakan Fiskal. Jakarta: PT RajaGrafindo Persada.

Mintarti, Nana. dkk,. 2012. Indonesia Zakat \& Depelopment Report 2012: Soal Kebijakan dan Hal Lain yang Belum paripurna. Ciputat: Indonesia Magnifience of Zakat.

Moleong, Lexy J. 2010. Metodologi Penelitian Kualitatif. Bandung: Remaja Rosdakarya.

Muhammad Baqir ash-Shadar, Syahid. 2002. Keunggulan Ekonomi Islam, terj. M. Hashem, Cet 1. Jakarta: Pustaka Zahra.

Muhammad Hasbi Ash-Shiddieqy, Teungku. 1997. Pedoman Zakat. Semarang: PT Pustaka Rizki Putra.

Mursyidi. 2006. Akuntansi Zakat Kontemporer. Bandung: PT Remaja Rosdakarya.

Nawawi, Ismail. 2010. Zakat dalam Perspektif Fiqh, Sosial \& Ekonomi. Surabaya: Putra Media Nusantara.

N. Dunn, William, 1991, Public Policy Anaysis: An Introduction, Second Edition, Prentice-Hall. Inc., A. Simon \& Schuster Company, Englewood Cliffs, New Jersey.

Nugroho, Riant. 2011. Public Policy: Dinamika Kebijakan, Analisis Kebijakan, Manajemen Kebijakan. Jakarta: Elex Media Komputindo.

Parsons, Wayne. 2011. Public Policy: Pengantar Teori dan Praktik Analisis Kebijakan. Edisi Pertama. terj. Tri Wibowo Budi Santoso. Jakarta: Kencana Prenada Media Grup.

Purwanto, Erwan Agus, dan Dyah Ratih Sulistyastuti. 2012. Implementasi Kebijakan Publik: Konsep dan Aplikasinya di Indonesia. Yogyakarta: Gava Media.

Qadir, Abdurrahman. 2001. Zakat Dalam Dimensi Mahadhah Dan Sosial. Jakarta: Raja Garfindo.

Qardawi, Yusuf. 1997. Norma dan Etika Ekonomi Islam. Jakarta: Gema Insani Press.

2005. Spektrum Zakat Dalam Membangun Perekonomian Kerakyatan. Jakarta: Zikrul Hakim.

antar Nusa.

Quraish Shihab, M. 1992. Membumikan Al-Qur'an: Fungsi Dan Peran Wahyu Dalam Kehidupan Masyarakat. Bandung: Mizan.

Remi, Sutyastie Soemitro, dan Prijono Tjiptoherijanto. 2002. Kemiskinan dan Ketidakmerataan di Indonesia. Jakarta: Rineka Cipta.

Siswadi, Edi. 2012. Birokrasi Masa Depan: Menuju Tata Kelola Pemerintahan yang Efektif dan Prima. Bandung: Mutiara Press.

Shofwan Shalehuddin, Wawan. 2011. Risalah Zakat Infaq \& Sedekah. Bandung: Tafakur.

Stamboel, Kemal Aziz. 2012. Panggilan Keberpihakan: Straregi Mengakhiri Kemiskinan. Jakarta: Gramedia Pustaka Utama

Subandi. 2011. Ekonomi Pembangunan. Bandung: Alfabeta.

Sudewo, Eri. 2004. Manajemen Zakat: Tinggalkan 15 Tradisi, Terapkan 4 Prinsip Dasar, Jakarta: Institute Manajemen Zakat.
Sugiyono. 2012. Metode Penelitian Kombinasi. Bandung: Alfabeta.

2013. Memahami Penelitian Kualitatif Bandung: Alfabeta.

Suharto, Edi. 2009. Kemiskinan dan Perlindungan Sosial di Indonesia. Bandung: Alfabeta.

Sukirno, Sadono. 2011. Ekonomi Pembangunan: Proses, Masalah, dan Dasar Kebijakan. Jakarta: Kencana Prenada Media Grup.

Sumodiningrat, Gunawan. 2011. Membangun Perekonomian Rakyat. Yogyakarta: IDEA.

Surakhmad, Winarno. 1980. Pengantar Penelitian Ilmiah: Dasar Metoda Teknik. Bandung: Tarsito.

Thoha, Miftah. 2010. Perilaku Organisasi: Konsep Dasar dan Aplikasinya. Jakarta: Raja Grafindo Persada.

Thoha, Miftah. 2011. Ilmu Administrasi Publik Kontemporer. Jakarta: Kencana Prenada Media Grup.

Wahyu Herdianto, Ahmad. "Peran Negara Dalam Mengoptimalkan Zakat di Indonesia". Palembang: Fakultas Syari'ah IAIN Raden Fatah.

Yunus, Muhammad. 2008. Menciptakan Dunia Tanpa Kemiskinan. Jakarta: Gramedia Pustaka Utama.

Zuhayly, Wahbah. 2008. Zakat Kajian Berbagai Mazhab. terj. Agus Effendi dan Bahruddin Fananny. Bandung: Remaja Rosdakarya.

\section{Website}

http://bps.go.id

http://data.tnp2k.go.id/file_data/Data/IKD/32_Jabar.pdf http://jabar.bps.go.id/subyek/jumlah-dan-persentasependuduk-miskin-dan-garis-kemiskinan-menurutkabupaten kota 